\title{
A new occurrence of microdiamonds in quartzofeldspathic rocks of the Saxonian Erzgebirge, Germany, and their metamorphic evolution
}

Massonne, H.-J.

Institut für Mineralogie und Kristallchemie, Universität Stuttgart, Azenbergstr. 18, D-70174 Stuttgart, Germany

\section{Introduction}

Very recently, Massonne et al. (1998) reported a method for polishing rock thin-sections suitable to quantitatively detect microdiamonds that are exposed at the polished surface by a peculiar striation pattern around them. Using this method, which was already successfully applied to diamondiferous quartzofeldspathic rocks of the Kokchetav Massif in Northern Kazakhstan (Massonne et al., 1998), a gneiss from the Saxonian Erzgebirge was also recognized to contain microdiamonds enclosed in garnet. This sample was conspicuous because of the abundant garnets of similar grain size (around $1.5 \mathrm{~mm}$ ) having rather peculiar potatoe-like shapes. In looking for these characteristics, a new sampling campaign in the Erzgebirge was successful, leading to the recognition of further diamondiferous quartzofeldspathic rocks, which were so far unique only in the Kokchetav Massif.

\section{Geological setting}

The crystalline massif of the Erzgebirge is located in Saxony and the Northern Czech Republic. Like other basement areas in Central Europa, it is part of the Variscides, which are widely covered by younger strata. The crystalline massif of the Erzgebirge forms an oval-shaped antiformal structure extending nearly 80 kilometers in NE-SW direction. In its central portion, predominantly ortho- and paragneisses occur that show numerous lenses of eclogites formed at metamorphic temperatures around $800^{\circ} \mathrm{C}$ (Massonne, 1994) or above (Schmädicke et al., 1992). In this so-called „Gneiss-Eclogite Unit“ a relative large lense of garnet peridotite also appears. The diamondiferous gneisses were found in this unit at or near the eastern shore of the Saidenbach reservoir, about 1.5 $\mathrm{km} \mathrm{NE}$ of Forchheim.

\section{Parageneses and mineral compositions}

The diamondiferous gneisses show abundant quartz, plagioclase and potassic white mica besides 10 to $20 \mathrm{Vol} \%$ of garnet. Kyanite crystals occur in some samples as relics. They are at least partially replaced by potassic white mica. K-feldspar can be occasionally present, as well. Minor constituents but omnipresent are zircon and rutile. Biotite appears only as replacement product of potassic white

Tab. 1: Structural formulae of garnet and kyanite analyzed by a Cameca SX-50 microprobe from diamondiferous gneisses. I = core, II = intermediate zone, III = rim of garnet

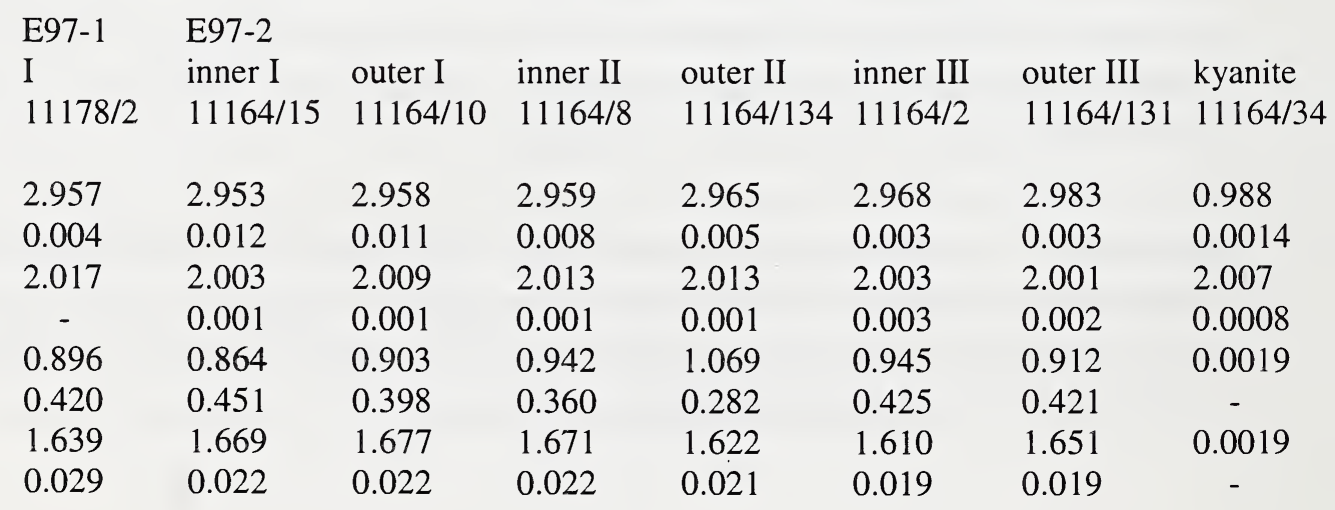


mica in very small amounts. Diamonds as large as $25 \mu \mathrm{m}$ are enclosed in garnet, kyanite and zircon. For instance, in sample E97-2 about 140 microdiamonds could be detected being exposed on a 6 $\mathrm{cm}^{2}$ surface area. In this sample microdiamonds were also unequivocally identified lying below the polished surface. Graphite pseudomorphs after diamond can be abundant in the investigated gneisses. Moreover, graphite flakes occur in the matrix of all diamondiferous samples. This is also the case in diamondiferous gneisses from the Kokchetav Massif. Thus, it seems to be an important feature for this rock type.

Detailed electron microprobe work was undertaken for four diamondiferous gneisses from the Erzgebirge and for two gneisses from the Kokchetav Massif for comparison. The latter rocks also contained microdiamonds enclosed in garnet and zircon. However, they showed abundant biotite and only minor potassic white mica. In addition to spot analyses, element distribution maps (Bernhardt et al., 1995) of several garnets and micas were prepared.

Garnets from all samples show virtually the same chemical zonation patterns. They can be subdivided into three zones. A core region shows slight zonation by increasing $\mathrm{Mg}$ and decreasing Ca contents (Tab. 1). According to the shape of this zone the garnets were xenomorphic at this stage. Ti contents reach their maximum at the rim of the core zone. Surprisingly, the compositions of this inner garnet zone can differ among the garnets of one sample significantly. An intermediate zone is characterized by a further increase of $\mathrm{Mg}$ and decrease of $\mathrm{Ca}$ which, however, is very clear compared to the core zone. In the rim zone of garnet, which is only occasionally developed, a decrease of $\mathrm{Mg}$ and an increase of $\mathrm{Ca}$ can be observed. In addition, a maximum of the $\mathrm{Cr}$ content can be related to the inner portion of the rim zone. Microdiamonds and graphite pseudomorphs appear exclusively in the intermediate zone of garnet. So far, no evidence was found that phengite formed together with diamond, but in the gneisses from the Erzgebirge an earlier stage of phengite formation can be traced due to white mica inclusions in the core zone of garnet. These phengites show a distinct composition from those included in other garnet zones and those of the matrix (see Tab. 2).

\section{P-T evolution}

Metamorphic conditions were derived at least partially by applying thermodynamic calculations. The Ti content of potassic white mica was used as a geobarometer (Massonne et al., 1993) and a revised Fe-Mg exchange thermometer for the phengite-garnet pair (Massonne, 1997) was applied.

For the earliest metamorphic stage preserved in the diamondiferous gneisses of the Erzgebirge conditions around $700^{\circ} \mathrm{C}$ and 20 kbar were calculated (Fig. 1). Because the chemical composition of the garnet core tends to be equalized by thermal diffusion, the temperature estimate refers rather to a maximum temperature for this early stage. Subsequently, pressures increased dramatically up to $40 \mathrm{kbar}$ or more so that diamond was formed. The phengite broke down to form kyanite and a potassic phase which might then be a fluid, K-feldspar or even a potassic cymrite. Because no clear evidence was found so far for which potassic phase was present at the peak $\mathrm{P}$ conditions, it is impossible for the moment to derive a value for the corresponding water activity. Temperatures increased with rising $\mathrm{P}$ to a range between $900^{\circ}$ to $1000^{\circ} \mathrm{C}$ resulting in a significant Ti solubility in garnet. This temperature estimate was obtained by comparison of garnets with rutile inclusions formed at various metamorphic temperatures. During the exhumation to levels related to metamorphic pressures between 15 to $20 \mathrm{kbar}$ the intermediate zone of garnet was formed and diamond crystals were enclosed. The corresponding uplift rate is assumed to be very high, although temperatures decreased to about $750^{\circ} \mathrm{C}$. At the end of this stage, phengite was newly formed but was still coexisting with kyanite. The subsequent metamorphic evolution derived here is similar to that deduced by Willner et al. (1997), who reported an exhumation of the gneisses at slightly decreasing temperatures starting at about $60 \mathrm{~km}$ depth only. Therefore, the question arises which portion of the „Gneiss-Eclogite Unit“ was object of the ultra-high pressure metamorphism. 
The metamorphic evolution for the diamondiferous gneisses of the Kokchetav Massif might be very similar to that described above.

Tab. 2: Structural formulae of phengites (double formulae unit) analyzed by a Cameca SX-50 microprobe from diamondiferous gneisses.

E97-1 inclusion matrix, matrix, inclusion in garnet core rim in garnet zone I $11177 / 3$

$11177 / 16 \quad 11177 / 35 \quad 11177 / 48$

$\begin{array}{lcccc}\mathrm{Si} & 6.565 & 6.476 & 6.367 & 6.462 \\ \mathrm{Al} & 4.297 & 4.564 & 4.727 & 4.431 \\ \mathrm{Cr} & 0.003 & 0.005 & 0.005 & 0.002 \\ \mathrm{Ti} & 0.258 & 0.215 & 0.235 & 0.329 \\ \mathrm{Mg} & 0.727 & 0.598 & 0.521 & 0.651 \\ \mathrm{Mn} & 0.006 & - & 0.004 & 0.001 \\ \mathrm{Fe}^{2+} & 0.172 & 0.167 & 0.174 & 0.118 \\ \mathrm{Ba} & 0.012 & 0.017 & 0.011 & 0.005 \\ \mathrm{Na} & 0.084 & 0.070 & 0.060 & 0.103 \\ \mathrm{~K} & 1.674 & 1.710 & 1.706 & 1.548 \\ \mathrm{~F} & 0.029 & 0.048 & 0.044 & 0.031 \\ \mathrm{OH} & 3.971 & 3.952 & 3.956 & 3.969\end{array}$

Fig. 1: P-T evolution of the diamondiferous gneisses from the Erzgebirge.

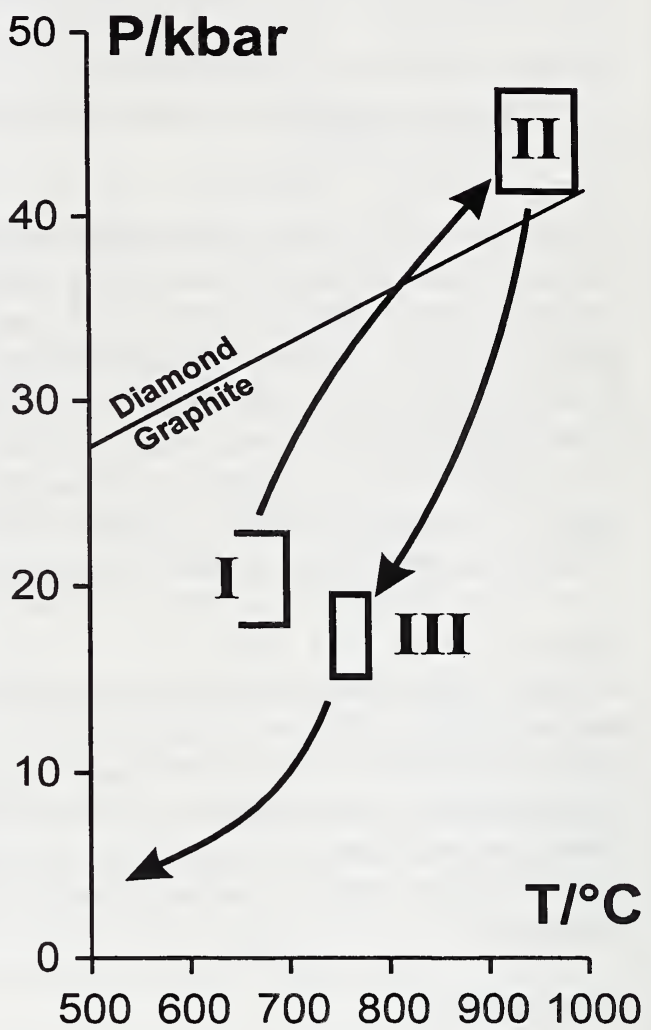

\section{References}

Bernhardt, H.J., Massonne, H.-J., Reinecke, T., Reinhardt, J. and Willner, A., 1995, Digital element distribution maps, an aid for petrological investigations: Ber. Dt. Mineral. Ges., Beih. Eur. J. Mineral., 7, No. 1, 28.

Massonne,H.-J., 1994, P-T evolution of eclogite lenses in the crystalline complex of the Erzgebirge, Middle Europe: an example for high-pressure to ultrahigh-pressure metabasites incorporated into continental crust: First Workshop on UHP metamorphism and tectonics, Abstr. Vol., 29-32.

Massonne, H.-J., 1997, An improved thermodynamic solid solution model for natural white micas and ist application to the geothermobarometry of metamorphic rocks: Geol. Surv. Finland, Guide 46, Mineral equilibria and databases, Abstracts, 49.

Massonne, H.-J., Grosch, U., and Willner, A., 1993, Geothermobarometrie mittels Ti-Gehalten in Kalihellglimmern: Ber. Dt. Mineral. Ges., Beih. Eur. J. Mineral., 5, No. 1, 85.

Massonne, H.-J., Bernhardt, H.J., Dettmar, D., Kessler, E., Medenbach, O., and Westphal, T., 1998, Simple identification and quantification of microdiamonds in rock thin-sections: Eur. J. Min., in press.

Schmädicke, E., Okrusch, M., and Schmidt, W., 1992, Eclogite-facies rocks in the Saxonian Erzgebirge, Germany: high pressure metamorphism under contrasting P T conditions: Contrib. Mineral. Petrol., 110, 226-241.

Willner, A.P., Rötzler, K., and Maresch, W.V., 1997, Pressure-temperature and fluid evolution of quartzo-feldspathic metamorphic rocks with a relic high-pressure, granulite-facies history from the Central Erzgebirge (Saxony, Germany): J. Petrol., 38, 307-336. 